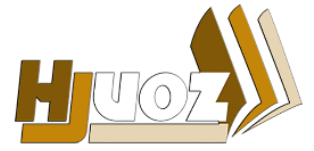

hjuoz.uoz.edu.krd p-ISSN: 2410-7557

e-ISSN: 25185128
كَوْارا زانستيّن مروّايهتى يا زانكوَيا زاخوّ

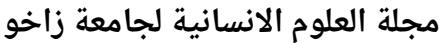

Humanities Journal of University of Zakho (HJUOZ)

Vol. 5, No. 1, pp. 389-401, March-2017

\title{
التوجه نحو الحياة لدى طلبة مدارس الاعدادية في مركز قضاء زاخو وعلاقته ببعض المتغيرات الاجتماعية و الثقافية
}

\author{
جيهان حسين عمر، زاهد سامي محمد، فمان أحمد محمد و نزار عصمت علي \\ قسم علم النفس العام، كلية التربية، جامعة زاخو، أقليم كوردستان - العراق.
}

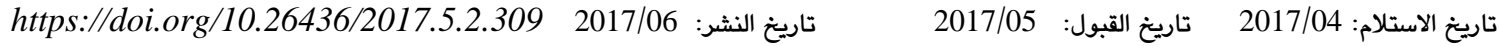

يهدف البحث الحالي إلى التعرف على التوجه نحو الحياة لدى طلبة مدارس المرحلة الإعدادية في مركز قضاء زاخو وعلاقته ببعض المتغيرات الاجتماعية و الثقافية والتعرف على الفروق تبعا للمتغيرات (الجنس، والمرحلة الدراسية ، والحالة الاقتصادية، و مستوى التعليمي للوالدين، ومحل السكن وهل الوالدين " على قيد الحياة ، أولا ")، وتألفت عينة البحث من (271) طالب و طالبة اختيوا بطريقة عشوائية. أعتمد الباحثون مقياس جاهز ( ليونتيف، 1992) لتوجه نحو الحياة ، والمؤلفة من (20) فقرة مزدوجة ، وتم ترجمتها و استخراج الخصائص السيكومترية لها، وتم استخدام التكرارات، والترتيب التنازلي، والأوساط الحسابية، والإنحرافات المعيارية، والقيمة التائية لعينة الواحدة، والقيمة التائيةلعينتين مستقلتين، وتحليل التباين. وأشارت النتائج الى وجود توجه إيجابي نحو الحياة لدى غالبية أفراد عينة البحث مع عدم وجود فروق ذا دلالة إحصائية

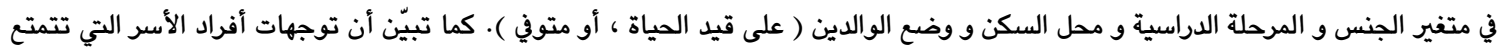
بوضع اقتصادي جيد نحو الحياة ايجابية أكثر من غيرها، وكذلك عندما يكون كلا الوالدين متعلمين. على ضوء ذلك قدم الباحثون مجموعة من

التوصيات والمقترحات.

الكلمات الدالة: التوجه نحو الحياة، طلبة مدارس المرحلة الإعدادية، قضاء زاخو، التعرف على المتغيرات الاجتماعية والثقافية.

Груздова, ) بالأحاسيس والعواطف و الجانب الثقافي لديه 63: 2008 )، و بعض التربويين يربطون بين القيم الانساني و منها قيم الفردية والاجتماعية المختلفة و بين أهداف والمعنى والتوجه نحو الحياة لديه، مما يؤثر على فهمه لنفسه في الظروف الحياتية المختلفة، وأن هذه العلاقة يؤثر بصورة الفعالة في التقدم التربوى للمجتمع وعملية Амельченко, التعليم والتعلم وتطوير العاملين في هذا المجال

. ( Кудашев, 2008 :83 “ 2009 :54

كما إن شيوع قيم و ثقافة التطرف والتعصب والعدوان و الإرماب تؤدي إلى التوتر والخلل في الأمن النفسي لدى الفرد والمجتمع وتؤدي إلى تشيع حالة من الخوف والفوضى والتهديد المستمر للوجود ويخلق ردود أفعال مضادة تؤدي إلى عدم الاستقرار و تترتب نتائج خطيرة تقود إلى الانهيار بالفرد و المجتمع ( حسن، و دايني، 2006 :175 )، و يرجع ذلك إلى إلى وجود بعض التوجهات السلبية لدى الأفراد نحو أنفسهم و الآخرين مما يؤدي إلى ظهود و تفشي بعض السلوكات المضادة لديهم ضد الآخرين في المجتمع ما نشاهده يومياً في ألاجهزة الإعلامية. كثير من المختصيين في مجال علم النفس يعتبرون البحث عن معنى الحياة هو البحث عن الصراعات الداخلية لدى الانسان وهذا ما يؤكد عليه فرويد ضمن محاولته تحديد القوى الداخلية لدى الفرد بغرض Рубцов и Лебедева, 2002, ) الكشف عن معنى الحياة

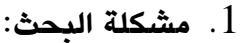

من خلال تجرية الباحثين بينت بأن للتوجه نحو الحياة المرامقين في المدارس تاثير في حياتهم بصورة عامة ومعناما بصورة خاصة. وخاصة ان طلبة مدارس الإعدادية في مرحلة انتقالية و حساسة، ويتعرضون لضغوط نفسية واجتماعية واقتصادية تدفعهم أحيانا إلى الشعور بعدم جدوى حياتهم المدرسية و العادية، لذلك ومن خلال مقابلات الباحثين مع عدد من الطلبة المراهقين في المدارس الإعدادية قرروا في إجراء دراسة علمية ميدانية في هذا المجال، وفي ضوء ما ذكر أعلاه يمكن صياغة مشكلة البحث بالتساؤلات الآتية 1. ما توجهات طلبة المرحلة الإعدادية نحو الحياة ؟ 2. ما المتغيرات التي تؤثر على توجهات طلبة المرحلة الاعدادية نحو

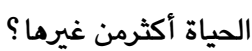

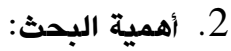

يؤكدالتربويين أن التوجهات المعاصرة في مجال بناء شخصية الفرد لاتتوقف فقط على الجانب المعرفي والعقلي، بل حسب رأي كبار علماء النفس الروس مثل فيكوتسكى وليونتيف و روبينشتاين وآخرون أن الجانب الآخر مهم أيضا في بناء الشخصية، بل يقع كثيرا على عاتق التوجهات القيمية لديه ، يرجع السبب في أن للتوجهات القيمية علاقة 
التعريف النظري للتوجه نحو الحياة : هي مجموعة من التصورات و المعتقدات والمبادئ الأساسية التي يكونها الفرد من خلال تفاعله اليومي مع البيئة الاجتماعية المحيطة به، و يكون رؤيته للعالم على مبنيا عليها. التعريف الإجرائي للتوجه نحو الحياة: هي الدرجة التي يحصل عليها المستجيب على مقياس التوجه نحو الحياة المعتمد في البحث الحالي.

6. خلفية نظرية ودراسات سابقة:

1.6. مفهوم التوجه نحو الحياة أو معنى للحياة: يعد مفهوم التوجه نحو الحياةLife oriention من المفاهيم التي قليلا ما درست من قبل علماء النفس، بالرغم من أنها من المواضيع التى إهتم به الفلاسفة، حيث يرى (يو. أ. بلوتنيكوفا) أن مضمون مفهوم التوجه نحو الحياة يحتوي على رضاء الفرد عن مبادئه الأخلاقية و متطلباته ألتي يمشي مع الأنظمة القيمية لديه، كما و مع استعداداته

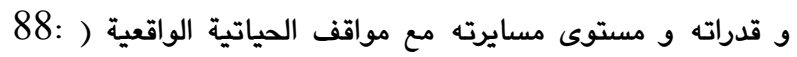
و 2001 احساس بان الفرد يتوجه نحو طريق التي له قيمة و تثمين ، و نحو

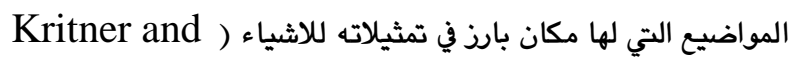
. Knicki, 2004 :277 ومن العلماء البارزيين الذين اهتموا بمفهوم التوجه نحو الحياة فيكتور فرانكل (1997- Victor Frankl, 1905 ) حيث بنى طريقته على (اسس) تجاربه في معتقلات النازيين ، عندما شاهد كثير من السجناء فقدوا آمالهم في المعتقل. إذ لاحظ فرانكل أن الأفراد الذين ينجون من حتمية الموت والدمار هم الذين بنوا شعور وعيهم على اساس المعنى ، وفي كثير من الاحيان شيء الوحيد الذي كانوا يريدونه هؤلا ءالاثخاص هوالحرية ، أو بالأحرى حرية اختيار اتجاهاته مهما كانت الظروف (575: Coon, 1997 ) لاحظ فرانكل أن توجه الفرد الإيجابي نحو الحياة و المستقبل سوف يساعدهم على تحمل الصعويات والمعاناة بشكل اكبر، و يرتفع مستوى التحمل لدى الانسان ويغير من مفاهيم وافكار سلبية نحو افكار ايجابية ،وينى طريقته العلاجية على هذا الاساس.(طولي، 43:2015، طولي، 2013 :6). يعتقد فرانكل

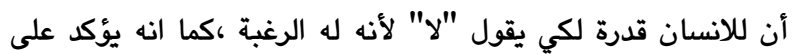

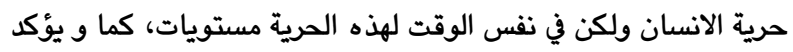

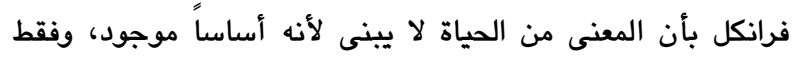
يحتاج إلى البحث عنه( 126 - -118:

.(Петровский и Ярошевский, 1996 :180) يعتقد فرانكل أن الشخص يكون انساناً عندما ينكر ذاته و يركز على

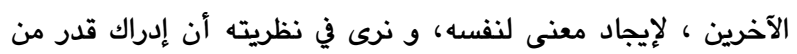
الثبات في حياة الواقعية و بحث في الوظائف هي التي تعطى للفرد معنى وجوده ( 10: Ruggiro, 2004 ) في دراسة قام بها فرانكل مع ويكي
91 ). كما و أكدت نتائج الدراسات على أهمية البحث عن معنى الحياة لدى الطلبة لها علاقته الوثيقة مع الجوانب المختلفة من حياتهم وعلى

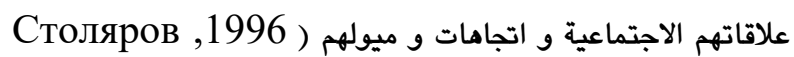

ومما سبق يمكن القول أن: 1-اللتوجهات الحياتية دور في تحديد شخصية الفرد المستقبلية. 2-كفاءة الفرد في أي مجال يعتمد على توجهاته الحياتية. 3-التوجهات الحياتية التي يحملها الفرد علاقة بالظرف الداخلية والخارجية له. 4-لتوجهات الأفراد نحو الحياة أثر على استقرا المجتمع وتقدمه. 3. اهداف البحث: يهدف البحث الحالي إلى ما يلي: 1- التعرّف على أولويات التوجه نحو الحياة لدى طلبة المرحلة الاعدادية بشكل عام وفقا لمقياس ليونتيف (1992). 2- تعرّف الفروق بين طلبة المرحلة الاعدادية في توجهاتهم نحو الحياة وفقا لمتغير: أ- الجنسبصورة عامة وترتيب الفقرات لديهم . أ- المرحلة الدراسية:(الرابع الإعدادي" العاشرة"، السادس الإعدادي" الثانية عشرة"). ب-موقع السكن:( في القرية، في المدينة). ت-الوضع الاقتصادي للعائلة:(جيد، متوسط، ضعيف). ث-الوضع التعليمي للوالدين:( الأب متعلم، الأم متعلمة، كلاهما متعلمان، كلامما غير متعلمان). وضع الوالدين من الحياة:( الأب حي، الأم حية، الأم ميتة، كلاهما حيان، كلاهما ميتان).

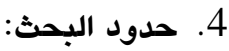
يقتصر البحث الحالي على معرفة التوجه نحو الحياة لدى كل من : أــ المجال البشري: الطلاب والطالبات المرحلة الإعدادية. ب-المجال المكاني : مركز قضاء زاخو. ت-المجال الزمني : للسنة الدراسية ( 2013 - 2014 ) . 5. تصديد المصطلحات: تعريف مفهوم معنى الحياة: يعرف ليوبومبر (leobolber )معنى الحياة: " بانه علاقة ذاتية مع معريف

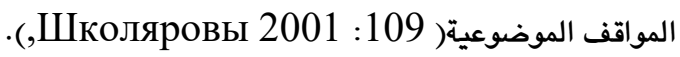
يعرف بي. سي. براتوس معنى الحياة: الحاجات الأساسية التي تؤثر

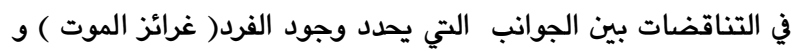

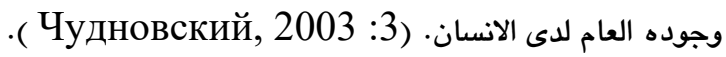
يعرف فرويد معنى الحياة:"بأنه المبادىء المبرمجة في اللذة ( غرائز

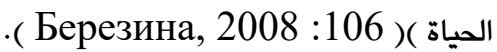


دراسة أ. ب. بويوجريسكي ( 1998 ) " تأثير مرض الجلطة القلبية على محور التوجه نحو الحياة لدى الانسان" و شكلت عينة البحث الحالية التجريبية عينتين التجريبية و الضابطة من المرض المصابين بالجلطة القلبية في مستشفيات الروسيا الاتحادية ( عمرهم بين 4050 سنوات )، و لتحقيق اهداف البحث استخدم الباحث مقياس التوجه نحو الحياة (دى. أ. ليونتيف) المتكون من (20) فقرة، و من النتائج الأساسية التي وصلت اليها الدراسة هي أن هناك فرق ذات دلالة احصائية بين التوجه نحو الحياة و خاصة في مجال مقياس الفرعي (لفي لهي الموقع الضبط ) لدى عينة الدراسة ولصالح المجموعة التجريبية .( Попогребский, 1998: 113 -128). 2.6. دراسة ذا علاقة بالموضوع: وهي كالآتي:

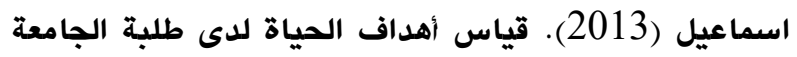
(بناء وتطبيق): هدفت الدراسة التعرف على أهداف الحياة لدى طلبة جامعة دهوك و علاقته بمتغير الجنس و المرحلة الدراسية، وتكونت

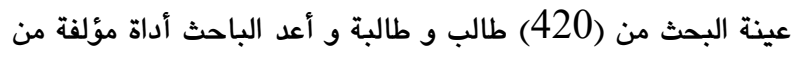

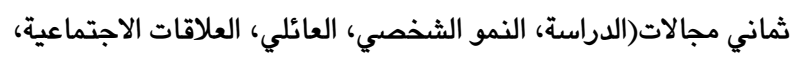
الصحي، الروحي، المالي، الترفيهي)، و استخرج الخصائص السيكومترية لها من صدق وثبات بأساليب متعددة، ويعد تطبيق الأداة بشكله النهائي، قام الباحث بمعالجة البيانات إحصائيا باستخدام الاختبار التائي لعينة واحد و لعينتين مستقلتين، وتوصلت الدراسة إلى بـ إلى امتلاك عينة البحث أهداف الحياة بشكل عام، كما أظهرت امتلاك أفراد عينة البحث أهداف الحياة لجميع مجالات الأداة فيما عدا المجال الصحي والمالي.كما وجد فروق ذات دلالة إحصائية لمجالين الأول المجال الروحي ولصالح عينة الإناث، و الثاني المجال المالي ولصالح عينة الذكور، أما بالنسبة للمرحلة الدراسية فكشفت عن وجود فروق في مجال أهداف الحياة المتعلقة بالمجال الدراسي و العائلي والمالي و كان الفرق لصالح طلبة المرحلة الرابعة(اسماعيل، 2013 : 1- 24). 7 . منهجية البحث و إجراءاته: اعتمد الباحثون المنهج الوصفي القائم على اجراء مسح ميداني لتحديد مجتمع البحث واسلوب اختيار العينة والاداة المستخدمة في قياس المتغير الذي يتناوله البحث وطريقة جمع البيانات والوسائل الاحصائية المستخدمة في معالجة البيانات الواردة في البحث وكما يلي:

1.7 أولاً: مجتمع البحث:

يعرف مجتمع البحث بأنه كل الأفراد الذين يحملون البيانات الظاهرة التي هي في متناول الدراسة، أو يقصد به جميع مفردات أو وحدات الظاهرة تحت البحث، المشتركة في صفة أو خاصية ما ( داؤد ، عبدالرحمن، 1990: 66)وقد تحدد مجتمع البحث الحالي بطلبة مدارس الإعدادية في مركز قضاء زاخو للعام الدراسي (2013-
مجموعة من الطلبة الذين حاولوا الانتحار (و فشلوا في ذلك) انه (85\%) منهم لم تكن لديهم معنى الحياة ، وفي نفس الوقت بينت الدراسة بان الاغلبية منهم (تقريبا 93\%) في كامل صحتهم الجسمية ،عاشوا في لئي ظروف مادية جيدة ،ومتكيفين مع عائلاتهم ،وكانت مشاركتهم مع المجتمع فعال جدا ، و كانت لديهم كل ما يحتاج المرء النجاح في حياتهم

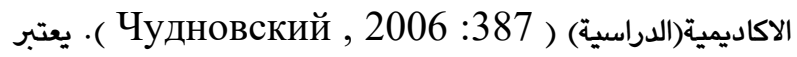
العلاج الوجودي لفكتور فرانكل احدى الطرق العلاجية التي يركز على اكتشاف الذات( , Gleitman, Fridlund and Reisberg 2004, 695 مساعدة المريض يوجه معنى وجوده في مواقف حياتية مختلفة Большой психологически словарь , 2007 ) 578: )، و مذا الفكرة تطابق مع وجهة نظر الطريقة الروجرزية في العلاج حيث تؤكد على قيم الفرد في عملية علاجه مما يساعده على تحديد معنى حياته ( 471: و عندما يبنى المريض ذاته على أساس هذا المعنى و يوجد معنى لحياته يستطيع مقاومة المشاكل و المعانات و الصعويات بشكل أفضل لهل ومستوى عال من الامكانات، و هذا ينخفض حدة الضغوطات لديه و يساعده على تحملهم و بالتالي يقترب من العلاج النهائي. ويصف عالم النفس البولوني ئوبوخوفسكي التوجه نحو الحياة و معنى الحياة، كالطائر الذييحتاج ليطير، يرى بان الانسان البالغ الكامل

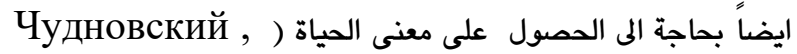

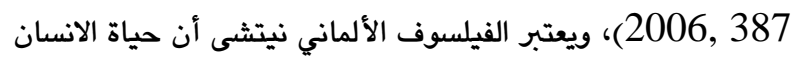
بدون معنى إن لم يكن قادرا على اعطاء جواب لسؤالٍ حول معنى الحياة

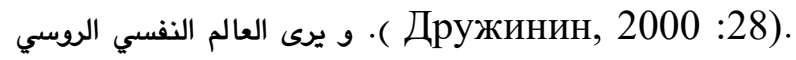
روبينشتاين أن معنى الحياة لكل فرد مرهون بعلاقاته مع الناس الآخرين ( Рубинштейн, 1997:77 )، كما و يرى العالم الكبير أنيشتاين بأن أفراد الذين لايعطون لحياتهم معنى ليس فقط غير

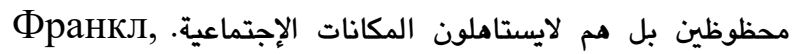
.(1990:36) 2.6. دراسات سابقة : سعى الباحثون في الحصول على دراسات سابقة، ويقدمون الدراسات

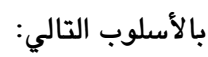
1.2.6. دراسات مباشرة عن الموضوع: دراسة محمد(2010)" التوجه نحو الحياة لدى طلبة كليات التربية"، شملت عينة البحث (252) طالب و طالبة من طلاب جامعات اقليم كوردستان العراق،و استخدم الباحث مقياس التوجه نحو الحياة (دى. أ. ليونتيف) المتكون هون من (20) فقرة ، و بينت النتائج بوجود علاقة بين التوجهات القيمية و التوجه نحو الحياة لدى أفراد العينة، كما أن لهذه التوجهات تأثير في

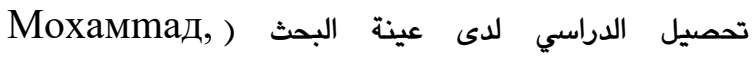
.2011:386-389 
الضرورية التي يحتاجونها للبحث الحالي( العيسوي، 1997، 153 )، و تكونت عينة البحث من (271)طالباً وطالبة بواقع (127) طالباً و (144) طالبة، وكما مو واضح في الجدول رقم (1). الجدول 1: يبيّن عدد أفراد عينة البحث وفقا لمتغير الجنس والمرحلة الدراسية

\begin{tabular}{|r|r|r|r|}
\hline 133 & 73 & 60 & السادس \\
\hline 271 & 144 & 127 & \\
\hline
\end{tabular}

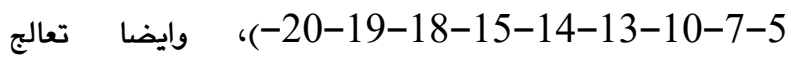

احصائياً حسب درجات (7-6-5-4-3-2-1) (1-10-10

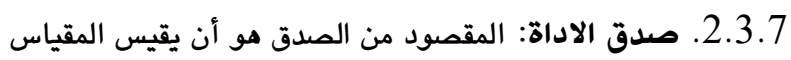
الشيء الذي نريد قياسه فعلا. ولكي يناسب الأداء موضوع الدراسة ومجتمعه، تم التحقيق منه من خلال التحليل المنطقي والتطابق بين

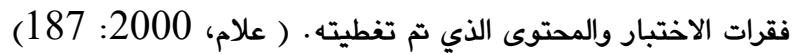

(Dunn, 2001:67)

ولأجل التحقق من صدق المقياس و صدق الترجمة اعتمد الباحثون على الصدق الظاهري و صدق المحتوى، و ذلك من خلال ترجمة المقياس من اللغة الروسية الى اللغة الكوردية و عرض الباحثون على مجموعة من المحكمين و الخبراء ، وطلبوا منهم الحكم على مدى صلاحية فقرات المقياس ويدائله وتعليمات الاجابة وتعديل ما يرونه مناسبا كما هو في الملحق(1)، وفي ضوء تقديرات واراء و ملاحظات البالغة (81\%) او اكثر، وتم التحقق منه من خلال تقديراتهم وأرائهم على صلاحية المقياس للغرض المعد من اجله. لكون أن المقياس يتألف من سبعة بدائل فقد اعطي لكل بديل ونن

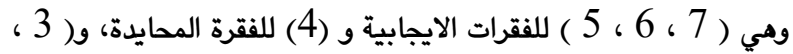
2، 1) للفقرات السلبية وحسب شدة و ونن الفقرة.

6.7. سادساً: الوسائل الاحصائية: معامل إرتباط بيرسون ( علام، 2000 : 118 )، والترتيب التنازلي للقيم الخام، والمتوسط الحسابي والمتوسط الفرضي، والانحراف المعياري لغرض وصف تباين الدرجات، و القيمة التائية (t-test) المحسوية للعينة الواحدة والقيمة التائية (t-test) المحسوية للعينتين المستقلتين، وتحليل التباين(ANOVA)، باستخدام البرنامج الإحصائي ( SPSS )(جودة، 2008 : 242 ).
2014) والبالغ عددهم (15654) منهم (7563) طالب و) و(8091)طالبة. 2.7 ثانياً: عينة البحث:

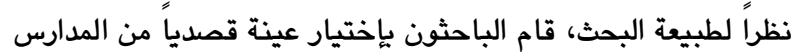
والمرحلة الدراسية ، وعشوائيا من الطلبة، لامتلاكهم المعلومات

\begin{tabular}{|c|c|c|c|}
\hline المجموع & اناث & ذكور & \\
\hline 138 & 71 & 67 & الرابع \\
\hline
\end{tabular}

3.7 - الثاً: الأداة البحث: 1.3.7. مقياس التوجه نحو الحياة: أ -عالم نفس الروسي الشهير دى. ئى.ليونتيف ( D. A. Liontev, 1992 ) وضع مقياس G. التوجه نحو الحياة بناءاً على جهود كل من ج.كرامبو (1) Crambo و ل. ماخوليكا (L. Makholika) في سنة 1964 (Crambo والتي يرجع اساساً الى فكرة فيكتور فرانكل في علاج المرضى على

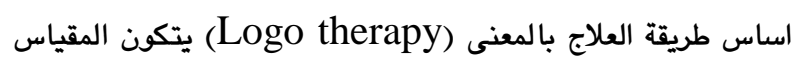

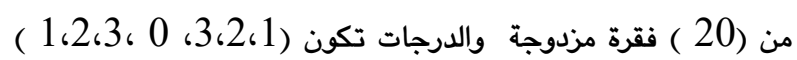
حيث يقوم المفحوص باختيار الفقرة حسب رأيه الشخصي وأهدافه الحياتية ، ويتكون المقياس من فقرات ايجابية وهذه الفقرات هي(1-

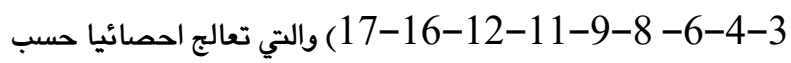
الترتيب السباعي(1-2-3-4-5-6-7) والفقرات سلبية هي(2-

المحكمين اعيد صياغة بعض الفقرات واجريت التعديلات اللازمة على بعضها ،وقد اعتبرت الفقرة صالحة اذا حظيت نسبة اتفاق المحكمين

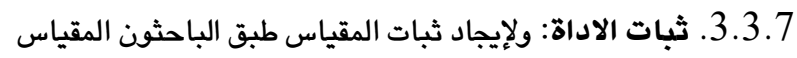
على عينة تألفت من ( 20 ) طالب و طالبة، ثم اعاد تطبيق المقياس على نفس الافراد بعد مرود اسبوعين تقريبا من التطبيق الاول (علام،

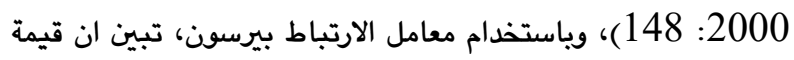
الارتباط بين نتائج التطبيق الاول و الثاني تساوي (75\%) ومهو ثبات يمكن الاعتماد عليه.

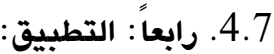
تطبيق المقياس على افراد عينة البحث التي بلفت ( 271 ) طالب و طالبة غير تلك المشمولين بالعينة الاستطلاعية و الثبات. 5.7 خامساً: تصحيح المقياس:

(1) مث الاعتماد على اراء د. نصرالدين إبراهيم محمد/ رئيس قسم علم النفس العام/

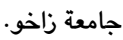


بعد إجراء التحليل الإحصائي باستخدام نظام ال ( SPSS ) تبيّن

أولويات توجهات طلبة المرحلة الإعدادية للحياة وفقا لمقياس

$$
\text { (ليونتيف، 1992)هي كما في الجدول(أولويات توجات الاعدادة) }
$$

8. عرض نتائج البحث ومناقشتها:

بعد إجراء تحليل البيانات إحصائيا وياستخدام برنامج الحقيبة

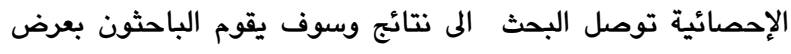
النتائج على وفق اهداف الدراسة وكالآتي: الهدف الأول: التعرّف على أولويات التوجه ندو الحياة لدى الدى طلبة المرحلة الاعدادية بشكل عام وفقا لمقياس (ليونتيف، (1992 الجدول2: يوضح ترتيب تنازلي للتوجهات التي يفضلونها طلبة المرحلة الاعدادية نحو الحياة بشكل عام

\begin{tabular}{|c|c|c|c|c|c|c|c|c|c|c|c|}
\hline القيمة التي & ترتيب & & القيمة التي & ترتيب & & القيمة التي & ترتيب & & القيمة التي & ترتيب & \\
\hline حصلت & الفقرة في & $=$ & حصلت & الفقرة في & $=$ & حصلت & الفقرة في & 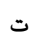 & حصلت & الفقرة في & $=$ \\
\hline عليها & الأداة & & عليها & الأداة & & عليها & الأداة & & عليها & الأداة & \\
\hline 1162 & 13 & 16 & 1218 & 17 & 11 & 1306 & 19 & 6 & 1410 & 3 & 1 \\
\hline 1149 & 8 & 17 & 1210 & 14 & 12 & 1301 & 20 & 7 & 1385 & 1 & 2 \\
\hline 1141 & 7 & 18 & 1209 & 5 & 13 & 1277 & 6 & 8 & 1370 & 4 & 3 \\
\hline 1129 & 16 & 19 & 1183 & 12 & 14 & 1270 & 10 & 9 & 1358 & 18 & 4 \\
\hline 1063 & 11 & 20 & 1174 & 2 & 15 & 1244 & 15 & 10 & 1343 & 9 & 5 \\
\hline
\end{tabular}

وباستخدام الاختبار التائي لعينة الواحدة تبين أن المتوسط الحسابي أكبر من المتوسط الفرضي كما هو موضح في الجدول

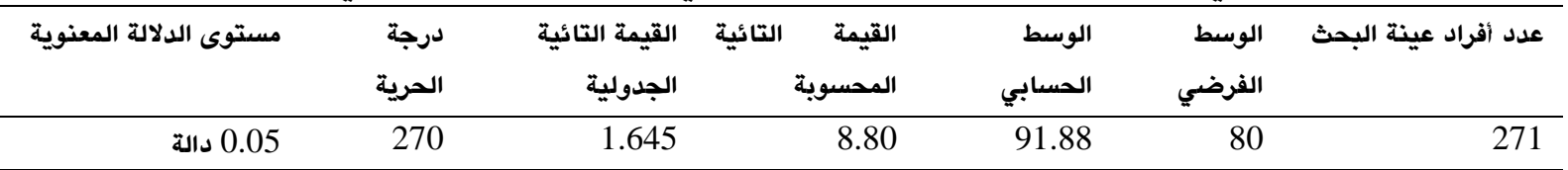

ب-المرحلة الدراسية:(الرابع الإعدادي" العاشرة"، السادس الإعدادي"

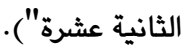

ت-موقع السكن:( في القرية، في المدينة).

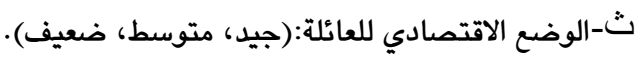

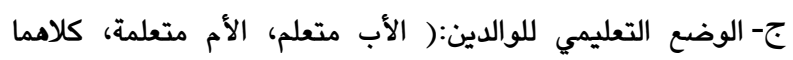
متعلمان، كلاهما غير متعلمان). وضع الوالدين من الحياة:( الاب حي، الأم حية، الأم ميتة، كلاهما

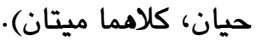

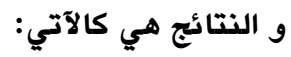
أ- توجهات عينة الإناث من الطلبة ندو الحياة لاتختلف من توجهات عينة الذكور ذلك، كما هو مبيّن في الجدول(4).
فأظهرت النتائج بوجود فرق ذات دلالة احصائية لدى الطالبات و الطلاب، إذ كانت القيمة التائية المحسوبة ( 8.80 ) عند مستوى دلالة داتل (6.05) و درجة الحرية ( 270 ) أكبر من القيمة التائية الجدولية (

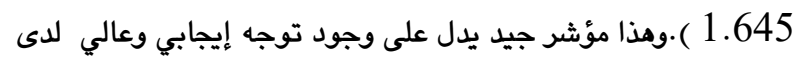

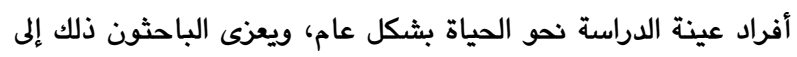
أن غالبية أفراد عينة البحث راضين عن مسير حياتهم ومتفائلين

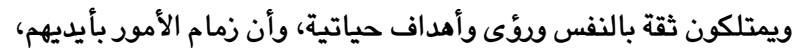

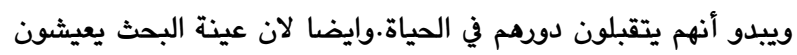
في مدينة تمتلك موقع جغرافي استراتيجي و مدخل تجاري لاقليم كوردستان حيث فرص العيش العمل فيها جيدة. أ - الجنس بصورة عامة وترتيب الفقرات لديهم .

الجدول 4: دلالة الفرق بين المتوسط الحسابي و النظري والقيم التائية المحسوبة و الجدولية لدرجات الطلبة حسب الجنس

\begin{tabular}{|c|c|c|c|c|c|c|c|}
\hline \multirow{2}{*}{ الدلالة } & \multirow{2}{*}{ مدرتوى الدلالة } & \multicolumn{2}{|c|}{ القيمة التائية } & \multirow{2}{*}{ الاندراف المعياري } & \multirow{2}{*}{ الحسابي } & \multirow{2}{*}{ العدد } & \multirow{2}{*}{ المجموعة } \\
\hline & & الجدولية & المحسوبة & & & & \\
\hline \multirow{2}{*}{ غير دالة } & \multirow{2}{*}{$\begin{array}{c}0.05 \\
(269)\end{array}$} & \multirow{2}{*}{2.326} & \multirow{2}{*}{1.2996} & 22.41475 & 85.3071 & 127 & الذكور \\
\hline & & & & 20.46463 & 97.6944 & 144 & الأناث \\
\hline
\end{tabular}

أصغر من القيمة التائية الجدولية ( 2.326 ) ، و يعني ذلك أن ليس

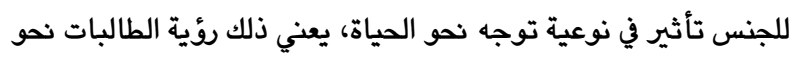

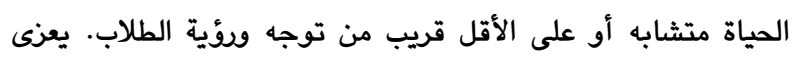

الجدول ( 4) يوضحعدم وجود فرق ذات دلالة احصائية بين توجه نحو

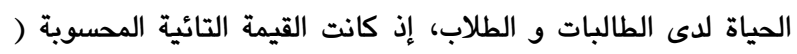

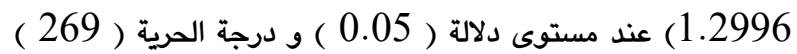


سلبية على الفقرات (5 ، 7 ، 11، 12 ، 13 ، 16) وشكواهم هي حول عدم امتلاكهم أهداف واضحة في الحياة، ويشكون من التكرار

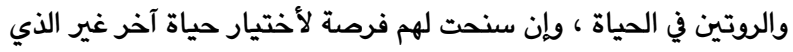
عاشوه فانهم لن يترددوا في القدوم إليها .كما هو في الجدول(5).
الباحثون هذا إلى أن الطالبات و الطلاب يواجهون المشاكل أو الظروف الحياتية بنفس الطريقة و لهذا الظروف تأثيرات متشابهة عليهم. بالرغم من عدم وجود فروق ذات دلالة احصائية بين آراء الذكور و الاناث ولكن تبين أن اختيارات عينة الإناث لجميع فقرات مقياس التوجه نحو مورد الحياة بشكل عام كانت إيجابية، بينما اختيارات عينة الذكور كانت

الجدول 5: يبين نتائج إجابات عينة البحث على كل فقرة المتوسط الحسابي لكل فقرة بترتيب تنازلي حسب توجهات الطلبة للحياة وفق متغير الجنس

\begin{tabular}{|c|c|c|c|c|c|c|c|}
\hline \multicolumn{4}{|c|}{ عينة الإناث } & \multicolumn{4}{|c|}{ عينة الذكور } \\
\hline & المتوسط & القيمة التي & & & المتوسط & القيمة التي & \\
\hline عبارة الفقرة & الحسابي & حصلت عليها & $ت$ & 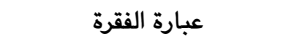 & الحسابي & حصلت عليها & ت \\
\hline & للفقرة & الفقرة & & & للفقرة & الفقرة & \\
\hline أهداف واضحة في الحياة & 5.514 & 794 & 1 & أهداف واضحة في الحياة & 4.775 & 616 & 1 \\
\hline غالبا أمتلك القدرة لإنجاز أعمال & 5.396 & 777 & 2 & يبدو لي حياة ذو معنى وهادفة & 4.76 & 614 & 2 \\
\hline حياتي مليئة بالأعمال والمتعة & 5.375 & 774 & 3 & غالبا أمتلك القدرة لإنجاز & 4.713 & 608 & 3 \\
\hline لدي القدرة على تحديد اتجاهاتي & 5.361 & 772 & 4 & لدي القدرة على تحديد & 4.543 & 586 & 4 \\
\hline يبدو لي حياة ذو معنى ومادفة & 5.278 & 760 & 5 & حياة معقولة & 4.426 & 571 & 5 \\
\hline 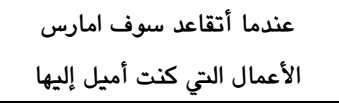 & 5.215 & 751 & 6 & حياتي مليئة بالأعمال والمتعة & 4.411 & 569 & 6 \\
\hline أعمالي اليومية محل رضاي و & 5.201 & 749 & 7 & بكل ثقة انا شخص هادف في & 4.388 & 566 & 7 \\
\hline أسيطر على مسار حياتي & 5.167 & 744 & 8 & أسيطر على مسار حياتي & 4.357 & 562 & 8 \\
\hline أيامي فيها تجدد وتنوع & 4.903 & 706 & 9 & أنا راضي عن أعمالي اليومية & 4.279 & 552 & 9 \\
\hline حياة معقولة & 4.854 & 699 & 10 & $\begin{array}{c}\text { أعتقد أن للفرد القدرة على اختيار الحياةو تحصيل } \\
\text { المكاسب }\end{array}$ & 4.171 & 538 & 10 \\
\hline اعتقاداتي حول الحياة غير واضحة & 4.84 & 697 & 11 & 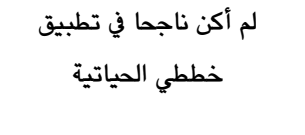 & 4.155 & 536 & 11 \\
\hline 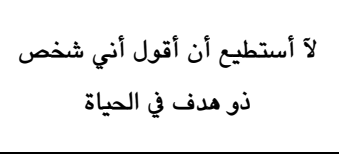 & 4.708 & 678 & 12 & $\begin{array}{c}\text { إذا تقدمت في السن و تقاعدت اشنارك في أي عمل أو } \\
\text { مشروع } \\
\text { أو }\end{array}$ & 4.14 & 534 & 12 \\
\hline 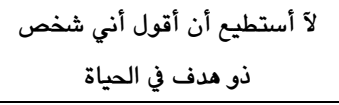 & 4.708 & 678 & 13 & أشعر ان حياتي رتيبة ومملة & 4.14 & 521 & 13 \\
\hline أعتقد أن الإنسان غير قادر ليختار & 4.694 & 676 & 14 & لا أمتلك رؤية واضحة ومحددة & 4.039 & 518 & 14 \\
\hline أشعر اني خاضع للظروف & 4.597 & 662 & 15 & 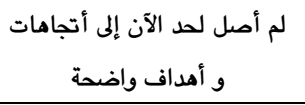 & 3.93 & 507 & 15 \\
\hline أشعر ان حياتي رتيبة ومملة & 4.556 & 656 & 16 & أشعر بأن الحياة غامضة & 3.915 & 505 & 16 \\
\hline $\begin{array}{c}\text { لو كانت لدي فرصة أخرى لإخترت } \\
\text { حياة جديدة }\end{array}$ & 4.465 & 643 & 17 & & 3.907 & 504 & 17 \\
\hline
\end{tabular}




\begin{tabular}{|c|c|c|c|c|c|c|c|}
\hline أشعر أن حياتي لم تسير حسب & 4.424 & 637 & 18 & حسب أماني و اني خاضع أن حياتي لم تسير & 3.907 & 504 & 18 \\
\hline لم أصل لحد الآن إلى أتجاهات و & 4.319 & 622 & 19 & بالنسبة لي ان احداث الحياة & 3.899 & 503 & 19 \\
\hline لم أكن ناجحا في تطبيق خططي & 4.285 & 617 & 20 & لو لإختر لدي فرصة أخرى & 3.256 & 420 & 20 \\
\hline
\end{tabular}

أـ ويالنسبة لمتغير المرحلة الدراسية تبيّن أن توجهات عينة المرحلة العاشرة من الطلبة نحو الحياة أفضل من توجهات عينة المرحلة الثانية عشرة، وذلك لأن الوسط الحسابي لإجاباتهم على أداة البحث أعلى من من مان الوسط الحسابي لإجابات المرحلة الثانية عشرة،و للتحقق من معنوية الفروق بين المجموعتين استخدم الباحثون الاختبار التائي لعينتين مستقلتين كما هو مبيّن في الجدول(6).
ويعزى الباحثون ذلك إلى أن للإناث أدوارا محدودة. وتطلعات أعلى في رسم مستقبل حياتهن،وقد يرجع ذلك الى طبيعة المجتمع و نظرته وتعامله مع الاناث بشكل يختلف عن الذكور · بينما في مذه الفترة العمرية يكون للذكور أدوارا شتى، ويسعون للإستقلال قبل الأوان

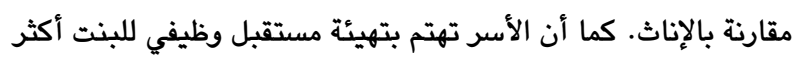
من الولد ويركزون في إعطائها الإرثادات أكثر من الشباب.

الجدول6: يوضح الأوساط الحسابية والانحرافات المعيارية لعينتي المرحلتين العاشرة والثانية عشرة.

\begin{tabular}{|c|c|c|c|c|c|c|c|}
\hline \multirow{2}{*}{ الدلالة } & \multirow{2}{*}{ مستوى الدلالة و } & \multicolumn{2}{|c|}{ القيمة التائية } & \multirow{2}{*}{ الانـراف المعياري } & \multirow{2}{*}{ المتوسط } & \multirow{2}{*}{ العدد } & \multirow{2}{*}{ المجموعة } \\
\hline & & الجدولية & المحسوية & & & & \\
\hline \multirow{2}{*}{ غير دالة } & \multirow{2}{*}{$\begin{array}{c}0.05 \\
(269)\end{array}$} & \multirow{2}{*}{2.326} & \multirow{2}{*}{1.789} & 20.68358 & 95.0075 & 138 & المرحلة العاشرة \\
\hline & & & & 23.50097 & 88.8496 & 133 & المرحلة الثانية عشر \\
\hline
\end{tabular}

حينما ينتقلون من مرحلة أدنى(مرحلة الأساس) إلى مرحلة الإعدادية، مما يدفعهم إلى تبني توجه أعلى محو الحياة من سابقتها.

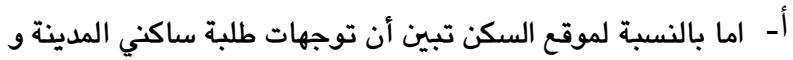
توجهات طلبة ساكني القرى نحو الحياة متقاربة لأن الوساط الحسابي للعينتين متقاربة ، وللتحقق من ذلك استخدم الباحثون الاختبار التائي لعينتين مستقلتين كما موضح في الجدول (7).
أظهرت النتيجة أن القيمة التائية المحسوية اقل من القيمة التائية الجدوليةو تعني ذلك عدم وجود فروق ذي دلالة إحصائية بين المرحلتين العاشرة والثانية، ويعزى ذلك الباحثون إلى شعور طلبة المرحلة الإعدادية بشكل عام باهتمام أكثر نحو المستقبلوذلك لتقرب فترة إيضاح مصير الفرد مما يدفع الطلبة إلى تكثيف جهودهم نحو تدقيق أحلام حياتهم. كما يرى الباحثون أن طلبة المرحلة العاشرة يشعرون باعتزاز أكثر لئر الجدول7: يبيّن الاوساط الحسابية والانحرافات المعيارية حسب المناطق السكنية لعينة البحث.

\begin{tabular}{|c|c|c|c|c|c|c|c|}
\hline \multirow{2}{*}{ الدلالة } & \multirow{2}{*}{ مستوى الدلالة و } & \multicolumn{2}{|c|}{ القيمة التائية } & \multirow{2}{*}{ الانحراف المعياري } & \multirow{2}{*}{ المتوسط } & \multirow{2}{*}{ العدد } & \multirow{2}{*}{ المجموعة } \\
\hline & & الجدولية & المحسوبة & & & & \\
\hline \multirow{2}{*}{ غير دالة } & 0.05 & \multirow{2}{*}{2.326} & \multirow{2}{*}{0.3387} & 26.98202 & 93.8235 & 17 & ساكن في القرية \\
\hline & $(269)$ & & & 21.94427 & 91.7598 & 254 & ساكن في المدينة \\
\hline
\end{tabular}

تبيّن أن توجهات عينة ذوي المستوى الاقتصادي الجيد نحو الحياة أفضل من توجهات عينة ذوي مستوى الاقتصادي المتوسط أو

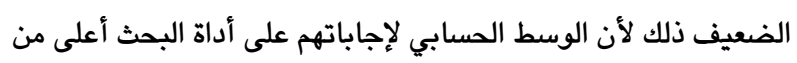
المتوسط الحسابي لإجابات عينة ذوي المستوى الاقتصادي المتوسط لهابط
وتبين أن القيمة التائية لم تكن دالة إحصائيا، ويعزى الباحثون ذلك إلى أن أسلوب حياة القرى والمدن بات قرييا من بعضها بالنسبة للطلبة، كما أنه في كلا الحالتين يكون الطلبة مشغولاً بواجباتهم الدراسية أكثر من أي شيء آخر.

$$
\begin{aligned}
& \text { أو الضعيف كما هو مبيّن في الجدول (8 و 9 9). } \\
& \text { الجدول 8: يوضح المتوسطات الحسابية والانحرافات المعيارية لتوجهات الطلبة حسب المستوى الاقتصادي لعوائلهم }
\end{aligned}
$$

\begin{tabular}{|c|c|c|c|}
\hline الإنحراف المعياري & الحسابي & العدد & الوضع المعيشي \\
\hline 20.72713 & 99.4237 & 118 & جيد \\
\hline 20.53659 & 86.3285 & 137 & متوسط \\
\hline 30.52751 & 83.9375 & 16 & ضعيف \\
\hline 22.24016 & 91.8893 & 271 & المجموع \\
\hline
\end{tabular}


الجدول9: يبيّن قيمة (ANOVA) والدلالة الإحصائية لمتغير المستوى الاقتصادي

\begin{tabular}{|c|c|c|c|c|c|c|}
\hline \multirow{2}{*}{ الدلالة (0.05) } & \multicolumn{2}{|c|}{ القيمة الفائية } & \multirow{2}{*}{ درجة } & \multirow{2}{*}{ متوسط المربعات } & \multirow{2}{*}{ مجموع المربعات } & \multirow{2}{*}{ المصادر } \\
\hline & الجدولية & المحسوية & & & & \\
\hline \multirow{3}{*}{ 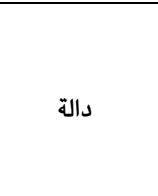 } & \multirow{3}{*}{3.02} & \multirow{3}{*}{13.165} & 2 & 5973.354 & 11946.709 & بين المجموعات \\
\hline & & & 268 & 453.739 & 121601.970 & داخل المجموعات \\
\hline & & & 270 & & 133548.679 & الكلي \\
\hline
\end{tabular}

ج- تبيّن النتيجة أن للحالة التعليمية للوالدين علاقة باتجاهات ابنائهم نحو الحياة ولصالح الوالدين المتعلمين و الأب المتعلم، فتكون أعلى مقارنة باتجامات أبناء(أم متعلمة) أو عندما تكون كليهما (أميين)، ويبين ذلك الجدول( 10 و 11 ) . اتجاهاتهم أكثر إيجابية نحو الحياة لأن الأوساط الحسابية لإجاباتهم

تم التحقق من ذلك باستخدام اختبار تحليل التباين(ANOVA) وتبين أنها كانت دالة إحصائيا ولصالح عينة المستوى الاقتصادي

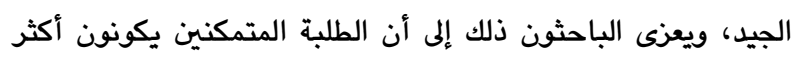
قدرة في توفير احتياجاتهم المادية والترويح عن أنفسهم مقارنة مع

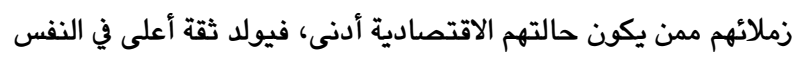
وشعور برضى أكثر نحو الحياة والمستقبل. الجدول10: يوضح المتوسطات الحسابية والانحرافات المعيارية لتوجهات الطلبة حسب الحالة التعليمية للوالدين.

\begin{tabular}{|c|c|c|c|}
\hline الإنحراف المعياري & المتوسط الحسابي & 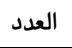 & الوضع المعيشي للعائلة \\
\hline 20.75208 & 90.5895 & 95 & الاب متعلم \\
\hline 19.85391 & 85.8000 & 10 & الام متعلمة \\
\hline 28.01785 & 86.0000 & 9 & الام غير متعلمة \\
\hline 20.53822 & 99.6047 & 86 & كلاهما متعلمان \\
\hline 23.56302 & 85.8873 & 71 & كلاهما اميان \\
\hline 22.24016 & 91.8893 & 271 & المجموع \\
\hline
\end{tabular}

\begin{tabular}{|c|c|c|c|c|c|c|}
\hline \multirow{3}{*}{$\begin{array}{c}\text { (0.05) } \\
\text { (0.05لالة }\end{array}$} & \multicolumn{6}{|c|}{ الجدول 11 :يوضح قيمة(ANOVA) ومستوى الدلالة الاحصائيةالمعيارية لتوجهات الطلبة حسب الحالة التعليمية للوالدين } \\
\hline & \multicolumn{2}{|c|}{ 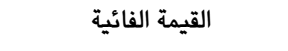 } & \multirow{2}{*}{ الحرجة } & \multirow{2}{*}{ متوسط المربعات } & \multirow{2}{*}{ مجموع المربعات } & \multirow{2}{*}{ المصادر } \\
\hline & 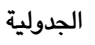 & المحسوبة & & & & \\
\hline \multirow{3}{*}{ دالة } & \multirow{3}{*}{2.39} & \multirow{3}{*}{4.532} & 4 & 2130.108 & 8520.433 & بين المجموعات \\
\hline & & & 266 & 470.031 & 125028.246 & 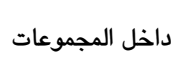 \\
\hline & & & 270 & & 133548.679 & الكلي \\
\hline
\end{tabular}

وللتحقق من ذلك تم استخدام اختبار تحليل التباين(ANOVA) ومتابعة أبنائهم في كيفية تحقيق تلك الأهداف مقارنة بالآباء غير وتبيّن أن قيمتها كانت دالة احصائيا ، ويعزى الباحثون ذلك إلى أن المتعلمة. ح- بالنسبة لتأثير حالة الوالدين على قيد الحياة أم لا.وعلى نمط و

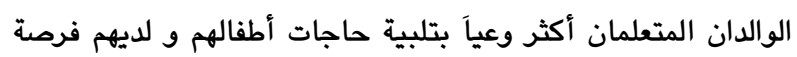

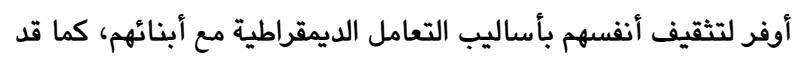
يكونون على وعي أكثر بأساليب وضع الخطط و الأهداف الواقعية الجدول12: يوضح قيمة(ANOVA) ومستوى الدلالة الاحصائيةلحالة الوالدين على قيد الحياة أم لا

\begin{tabular}{|c|c|c|c|c|c|c|}
\hline \multirow{2}{*}{$\begin{array}{c}\text { (0.05) } \\
\text { (0.05) }\end{array}$} & \multicolumn{2}{|c|}{ القيمة الفائية } & \multirow{2}{*}{ الحرية } & \multirow{2}{*}{ متوسط المربعات } & \multirow{2}{*}{ مجموع المربعات } & \multirow{2}{*}{ المصادر } \\
\hline & الجدولية & المحسوية & & & & \\
\hline \multirow{3}{*}{ غير دالة } & \multirow{3}{*}{2.62} & \multirow{3}{*}{1.660} & 3 & 815.162 & 2445.486 & بين المجموعات \\
\hline & & & 267 & 491.023 & 131103.193 & داخل المجموعات \\
\hline & & & 270 & & 133548.679 & الكلي \\
\hline
\end{tabular}


الجدولية ( 2.62 ). و يعزى الباحثون ذلك بأن الأفراد المتوفي الوالدين وغير المتوفيين تنضج لديهم في هذه الفترة مشاعر بالمسؤولية نحو تضمين مستقبل حياتهم لتحدي صعويات الواقع نظرا لدود المدرسة و الأهل في تقديم إرثادات والدعم المستمرلهم. 5-تشجيع الطلبة من قبل الوالدين والمدرسين والمدرسة ليشاركوا في نشاطات الثقافية ، الاجتماعية ،العملية والتطبيقية والانضمام للمنظمات الطلابية والاعلامية مما يزداد من مستوى الثقة بالنفس لديهم و يؤدي إلى تهيئتم للحياة المستقبلية بصورة مؤثرة. 6- إقامة برنامج إرثادي حول موضوع التوجه نحو الحياة للطلبة ذوي التوجه السلبي و تفهيمهم بأضرار مثل هذا التوجه لشخصيتهم و مستقبلهم الدراسي والحياتي بصورة عامة، والتركيز على موضوعات المتعلقة بها وإعطاء حلول مناسبة عملية لإزاحة مثل هذه الرؤية السلبية نحو الحياة لديهم.

10 10 المقترحات

استكمالاً للفوائد المتوخاة من الدراسة نقترح: إجراء دراسة مماثلة عن التوجه نحو الحياة لدى الطلبة وعلاقتها بمتغيرات اخرى غير تلك التي تناولها البحث الحالي ( موقع الضبط ، الثقة بالنفس، و بعض سمات الشخصية ، التقدير الذات، مفهوم الذات، الدافع المعرفي، اختيار الهدف، اتخاذ القرار و الإنجاز الأكاديمي...الخ).

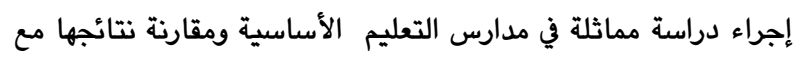
نتائج الدراسة الحالية. تقويم أثر أساليب التدريس و التعامل لدى المدرسين مع الطلبة من وجهة نظر الطلبة نحو الحياة. 11.المصادر باللغة الكوردية:

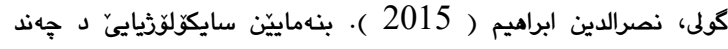

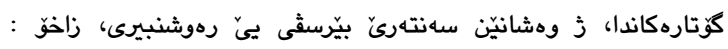

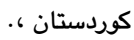
(...

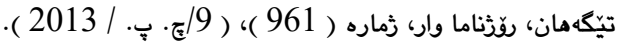

11 1. 11 المصادر باللغة العربية:

اسماعيل، أدهم اسماعيل خديدة(2013). قياس أهداف الحياة لدى طلبةالجامعة (بناءوتطبيق)، بحث منشور في مجلة أبحاث كلية التربية

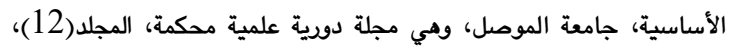

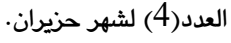

جودة، محفوظ(2008). التحليل الاحصائي الأساسي باستخدام SPSS دائل

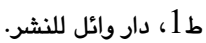
حسن، الحارث عبدالحميد . غسان حسين سالم دايني ( 2006 ). علم النفس الأمني، ط. 1، الدار العربية للعلوم، بيوت، لبنان.
أظهرت النتيجة بعدم وجود فرق ذات دلالة احصائية بين نمط توجه طلبة مرحلة الإعدادية نحو الحياة حسب متغير حالة الوالدين على قيد

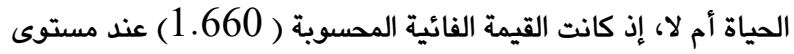
دلالة ( 0.05 ) و درجات الحرية (3 و 267 ) أقل من القيمة الفائية

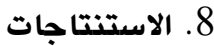

$$
\text { توصل البحث إلى: - n }
$$

1-أنأفراد عينة البحث بشكل عام يمتلكون توجهات ايجابية نحو

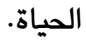

2-أن توجهات عينة الإناث وعينة مرحلة الرابع الإعدادي (العاشر) ايجابيةأكثر من عينة الذكور و مرحلة السادس الإعدادي( الثاني عشر). 3-أنتوجهات ذوي الوضع الاقتصادي الجيد والذين (والديهم متعلمين) أو (على قيد الحياة) يمتلكون توجهات ايجابية أفضل نحو الحياة من ذوي الوضع الاقتصادي ( المتوسط أو الضعيف)، من الذين (أحد والديهم متعلم أو كلاهما غير متعلمان). عدم وجود فروق جوهرية بين توجهات عينة البحث نحو الحياة ضمن الذين احد والديهم على قيد الحياة أو كلاهما على قيد الحياة أو كلامما ميتين، وكذلك بالنسبة للذين محل سكنهم القرية أو المدينة.

$$
\text { 9. التوصيات }
$$

$$
\text { على وفق نتائج البحث يوصي الباحثون ما يلي: }
$$
1-ضرورة إعادة النظر ببعض معايير تربية الطلبة في المدارس، و خاصة بما يتعلق بتعامل المدرسين مع الطلبة ليكون أكثر مشجعاً

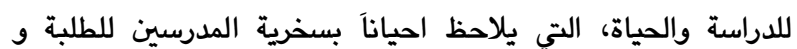
قدراتهم دون مراعاة الفروق الفردية بينهم. 2-اهتمام الوزارات المعنية بفسح مجالات أكثر لجوانب الحياة الثقافية مراهية والعلمية والاقتصادية والاجتماعية والصحية للشباب. 3-إتاحة فرص أكثر للمجالات التطبيقية، وتزويد الطلبة بمهارات حياتية (مهنية واجتماعية) يمكن لهم الاعتماد على أنفسهم بشكل أفضل في المستقبل، ذلك عن طريق إضافة مادة مهنية تطبيقية ضمن مناهج الدراسي في مرحلة الإعدادية ليعمل الطالب يوم واحد في الاسبوع في ورثة أو معمل لكي يتمكن الطالب اكتساب مهارة في مهنة ما مما يعطيه فرصة أكبر لكي يعتمد على نفسه و تزداد هذه الفرصة مستوى الثقة بالنفس لديه بعد تخرجه من المدرسة وخاصة أن فرصة الحصول على الجامعات و المعاهد أصبحت صعبة في السنوات الأخيرة. 4- إجراء زيارات ميدانية من قبل المدارس للأماكن المختلفة التي تزود الطالب بقناعات حياتية أفضل مثل: ( دور الأيتام، المستشفيات و أماكن الرعاية الإجتماعية للمسنين و الإصلاحيات وكذلك سفرات ترفيهية نحو مناطق الطبيعة الجميلة، ومعسكرات الطلبة الصيفية..الخ). 
Насраддин Е. Мохаммад ( 2010 ). Статус и динамика терминальных ценностей студентов педагогических вузов // Известия Российского государственного педагогического университета им. А. И. Герцена»،№121، 2010. с.132-135(0،2 п.л.).

Мохаммад، Насраддин Е. (2s011). Страктура и динамика ценносно-смысложизненных ориениаций студентов педагогичесаого вуза (на материале Салахаддин университета и Дахук университета Курдистана- Ирака). Канд. Дисс. -Москва. С. 154.

Петровский А.В., Ярошевский М.Г. (1996).История и теория психологии - Ростов-на-Дону, из-во . « феникс», $-416 \mathrm{c}$.

Попогребский А.П. (1998). Влияние инфаркта миокарда на смысловую сферу человека //Психологический Журнал.Том19 . № 5 . с. $113-128$.

Рубинштейн С.Л.( 1997 ). Человек и мир. М.: Наука ,$-191 \mathrm{c}$.

Рубцов А. В. , Лебедева С. В. (2002). Виртуальная психологическая служба : функциональны задачи особенности организации Психологическая наука и образование журнал . № 2. с. 91- 97.

Столяров И.Н. (1996). Место и роль христианской этики в формирование духовно-ценностных ориентаций молодёжи. : Автореф. Дис. Канд. Моск.

Франкл В.(1982). Поиск смысла жизни и логотерапия // Психология личности. Тексты. -M., 1982. - C. 118-126.

Франкл В. (1990). Человек в поисках смысла : сборник : пер.с анг. И нем. /общ.Ред. Л.Я. Гозмона и Д.А. Леоньева.-М.:Прогресс,.360c.

Чудновский В.Э. ( 2003 ).Психологические составляющие оптимального смысла жизни // Вопросы Психологи Журнал. № 3. с.3 - 13.

Чудновский В.Э. ( 2006 ). Становление личности и проблема смысла жизни. Избрание труды .М. из-во Моск. Психолого_социалного ин_та :Воронеж :из_во НПО «М МОДЭК»,_768с.

Школяровы, Любомир и Надежда ( 2001 ). Феноменология парадоксальных интенцтй сознания: непризнанные гении в поисках смысла своего бытия: нестандардный учебник философии личной жизни/Похилько А. Д. , Вьюков А. С., Гречаник И. В., Домбровская Т. И. , др. / под. Ред. Похилько А. Д.- Армавир: изд-леский центр АГПИ, 212.

$$
\text { ط1، العراق، ،اؤد عزيز، . أنور حسين عبد الرحمن (1990). مناهج البحث التربوي. }
$$

علام، صلاح الدين محمود(2000). القياس و التقويم التربوي و النفسي"

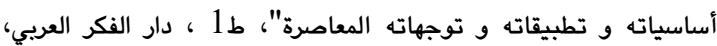

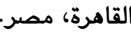

العيسوي، عبدالرحمن(1997). أصول البحث السيكولوجي"علميا ومهنيا"، دار الراتب الجامعية، بيروت، لبنان.

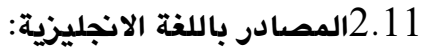

Coon, Dennis (1997). Essentials of psychology, exploration and application, 7 th, Brooks/Cole pub.USA.

Dunn, Dana S. (2001 ). Statistics and data analysis for the behavioral sciences.McGraw-Hill,582pp.

Gleitman, Henry, Fridlund, Alan J., Reisberg, Daniel. ( 2004 ). Psychology. $6^{\text {th }}$. Ed. Norton \&company, NY. London. 705pp.

Kreitner, Robert and Kinicki, Angelo ( 2004). Organizational behavior, $6^{\text {th }} \mathrm{ed}$. McGraw-Hill, Irwin ,710pp.

Ruggiro, S. ( 2004 ). Byondfeelings , A guid to critical thinking, $7^{\text {th }}$ ed. , McGraw Hill, NY., (237)p.

$$
\text { 3.11المصادر باللغة الروسية: }
$$

Амельченко, Т. В. (2009 ). социално педагогическое образование: содержание и стратегические ориентиры развития, Педагогическое образование т наука, но. 4, 50-55 c.

Большой психологически словарь (2007). Сост. иобш. Ред. Б.Г. Мещеряков, В.П. Зинченко. СПб.:Парим Еврознок,.627c.

Березина Т.Н. (2008). Смысла жизни ,добро, духовное развитие, определенное их знаяение. // Мир психологии журн. - № 2.том 54. - С.105-115.

Великие психологи( 2000 ). Серия «Исторические силуэты». Ростов,-576c.

Груздова, И. В. ( 2008 ). Игра-уподобление в музыкальном развитии детей дошкольного возраса, Педагогическое образование т наука, но. 6, 63-68c.

Дружинин В. Н. ( 2000 ). Варианты жизни: Очерки экзистенциальной психологии.-М: ПЕРСЭ:СПб.: Иматон-М, -135c.

Кудашев, Р.К. ( 2008 ). Организационнопедгогические предпосылки формирования культуры здаровья сиудентов в процессе физического воспитания, Педагогическое образование т наука, но. 9, 83-85с.

Леонтьев Д.А.( 1992 ).Тест смысложизненных ориентаций( СЖО ).- М., "СМЫСЛ"- 16 с. 
الملاحق

الملحق 1: اسماء الخبراء و المحكمين الذين تم الاستعانة بخبراتهم في صدق المقياس والترجمة من الروسية إلى الكوردية

\begin{tabular}{|c|c|c|c|c|}
\hline نوع الاستشارة & الفاكولتي و الجامعة & التخصص & الاسم والمرتبة العلمية & ت \\
\hline مدق ظاهري & صلاح الدين / التربية & الصحة و الشخصية & أ.د. يوسف حمة صالح مصطفى & 1 \\
\hline مدق ظاهري & صلاح الدين / آداب & علم الاجتماع & أ.د. عبدالمجيد غفور ابراهيم & 2 \\
\hline مدق ظاهري & صلاح الدين / آداب & علم الاجتماع & أ.د.طاهر حسو مير الزيباري & 3 \\
\hline مدق ظاهري & صلاح الدين / آداب & علم الاجتماع & أ. م.د. عبدالله خورشيد عبدالله & 4 \\
\hline مدق ظاهري & صلاح الدين / التربية & علم النفس & أ.م.د. ريزان علي إبرامم & 5 \\
\hline مدق ظاهري & صلاح الدين / آداب & 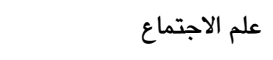 & أ.م.د. سليم بطرس الياس & 6 \\
\hline مدق ظاهري & صلاح الدين / التربية & الصحة النفسية والشخصية & أ.م.د. مؤيد اسماعيل جرجيس & 7 \\
\hline عدق ظاهري & صلاح الدين / آداب & علم الاجتماع & م.د. داود يوخنا دانيال & 8 \\
\hline صدق ترجمة المقياس من الروسية & صلاح الدين / الإدارة و الإقتصاد & الإدارة و الإقتصاد & م. د. دلير اسماعيل حقي شاويس & 9 \\
\hline صدق ترجمة المقياس من الروسية & زاخو / العلوم الإنسانية & علم النفس التربوي & م.د. نصرالدين ابراهيم محمد & 10 \\
\hline
\end{tabular}

لـاقوتابيى /يا بهريّز

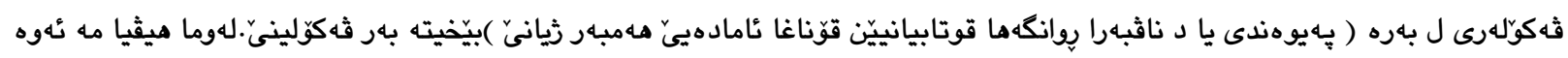

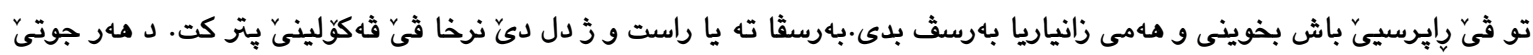

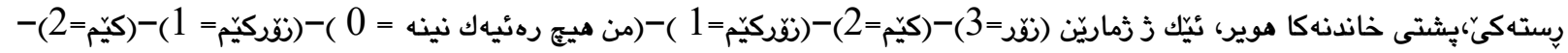

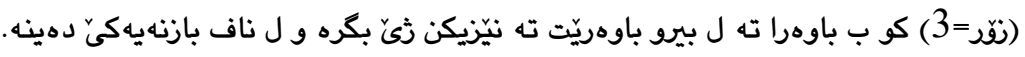

\begin{tabular}{|c|c|c|c|c|c|c|c|c|c|c|}
\hline 1 & 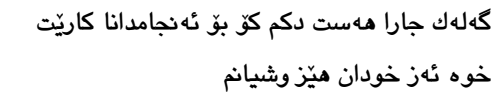 & 3 & 2 & 1 & 0 & 1 & 2 & 3 & 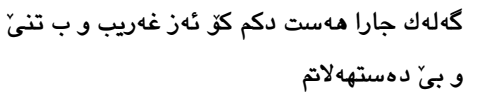 & $1 \square$ \\
\hline 2 & 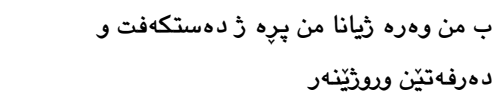 & 3 & 2 & 1 & 0 & 1 & 2 & 3 & هدست دكهم ريانا من ههمى روّتين و دوويارهيه & 2 \\
\hline 3 & من د ريانيّدا نامانجيّن روّهن و ديار يِين هـين & 3 & 2 & 1 & 0 & $1 \mid$ & 2 & 3 & من دثيانيّدا ج نارمانجهكا ديار نينه & 3 \\
\hline 4 & 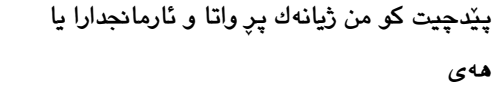 & 3 & 2 & 1 & 0 & 1 & 2 & 3 & يَّارمانجه & 4 \\
\hline 5 & 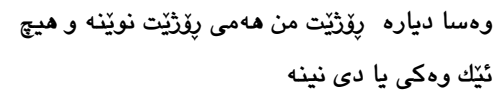 & 3 & 2 & 1 & 0 & 1 & 2 & 3 & 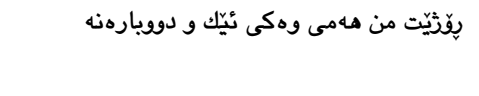 & 5 \\
\hline 6 & 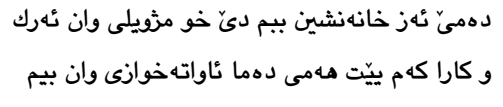 & 3 & 2 & 1 & 0 & 1 & 2 & 3 & 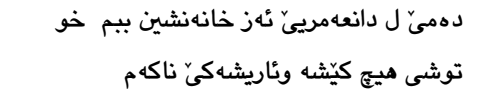 & 6 \\
\hline 7 & ثيانا من ب كثتى ودكى جهوا من دثيا برِيَّهدجيت & 3 & 2 & 1 & 0 & 1 & 2 & 3 & 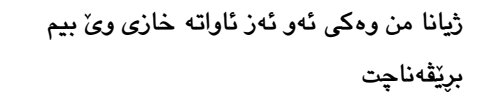 & 7 \\
\hline 8 & 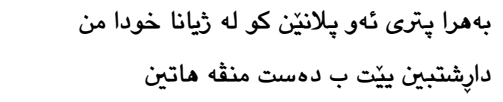 & 3 & 2 & 1 & 0 & 1 & 2 & 3 & 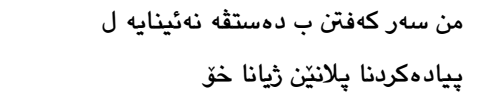 & 8 \\
\hline
\end{tabular}




\begin{tabular}{|c|c|c|c|c|c|c|c|c|c|c|}
\hline 9 & ثَيانا من بِرِه ذَ كاريّن خَّش و به دلَّ من & 3 & 2 & 1 & 0 & 1 & 2 & 3 & ثيانا من بوّش و بهتاله و بكَمهاعنايه & 9 \\
\hline 10 & 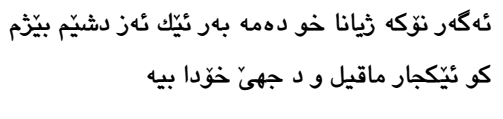 & 3 & 2 & 1 & 0 & 1 & 2 & 3 & 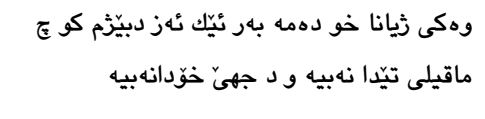 & 10 \\
\hline 11 & 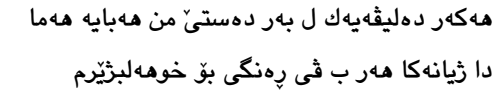 & 3 & 2 & 1 & 0 & 1 & 2 & 3 & 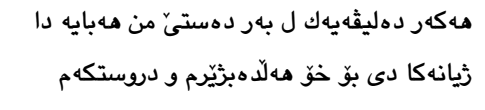 & 11 \\
\hline 12 & 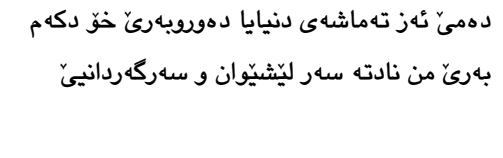 & 3 & 2 & 1 & 0 & 1 & 2 & 3 & 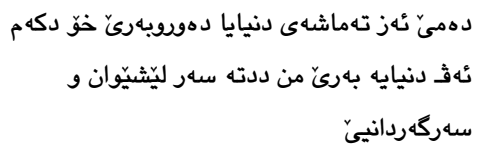 & 12 \\
\hline 13 & 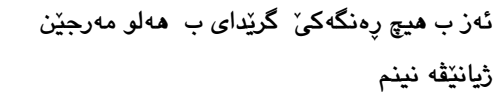 & 3 & 2 & 1 & 0 & 1 & 2 & 3 & ئهز بهيوهست و كريّداى ب هلو مهرجاثهمه & 13 \\
\hline 14 & 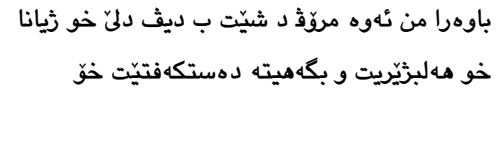 & 3 & 2 & 1 & 0 & 1 & 2 & 3 & 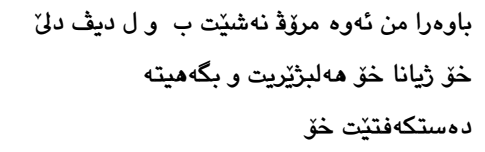 & 14 \\
\hline 15 & 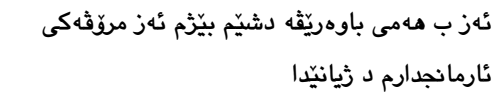 & 3 & 2 & 1 & 0 & 1 & 2 & 3 & 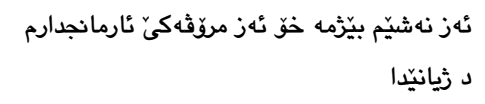 & 15 \\
\hline 16 & 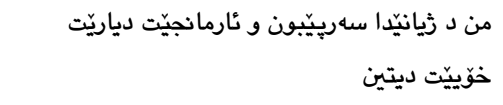 & 3 & 2 & 1 & 0 & 1 & 2 & 3 & 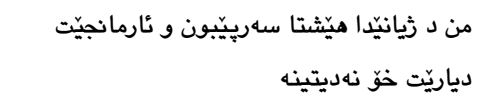 & 16 \\
\hline 17 & بئاشكرانه باوريّت من لسهر ريانى كَهله روّهن و & 3 & 2 & 1 & 0 & 1 & 2 & 3 & بَاشكرانينن باوريّت من ل دوّد ثيانى رِّهن و & 17 \\
\hline 18 & 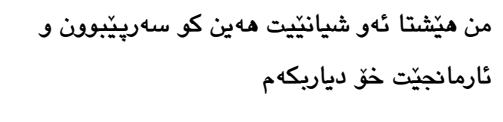 & 3 & 2 & 1 & 0 & 1 & 2 & 3 & 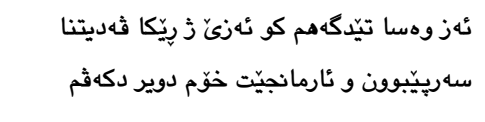 & 18 \\
\hline 19 & 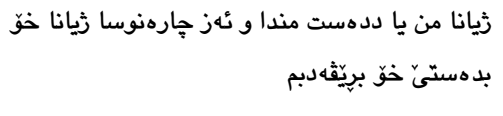 & 3 & 2 & 1 & 0 & 1 & 2 & 3 & 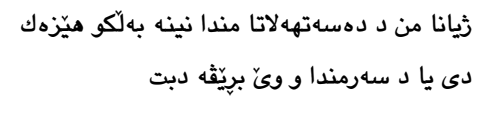 & 19 \\
\hline 20 & داريّت من يِّت روّذانه بوّ من جهى ردزامهندى و & 3 & 2 & 1 & 0 & 1 & 2 & 3 & 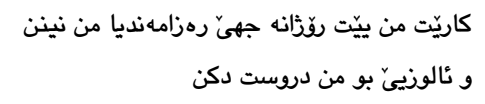 & 20 \\
\hline
\end{tabular}




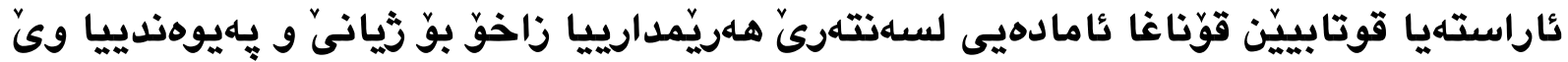 دكَل هندهك بكَّريّن جڤاكى و كهلتوورى
}

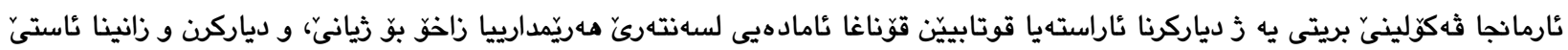

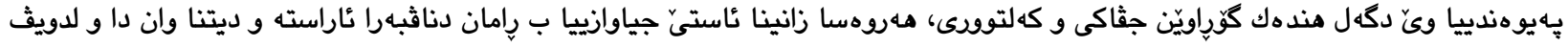

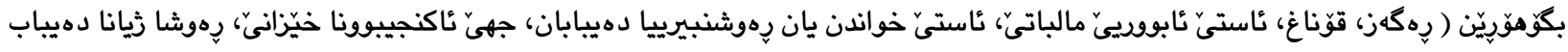

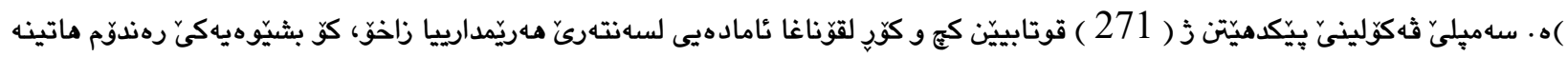

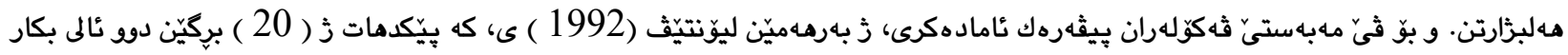

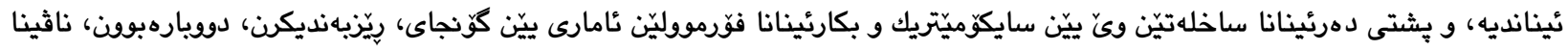

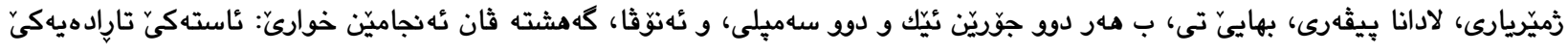

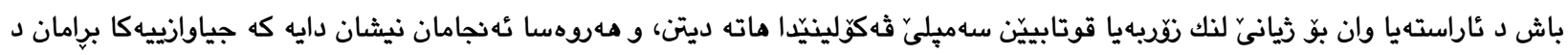

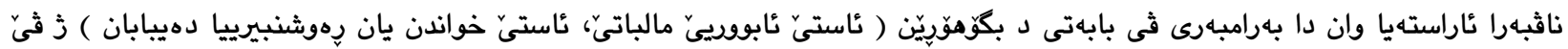
ثهكولينى دا هاتيه ديتن، نهخاسمه ئهو مالباتيّن باريّ ئابوورييا وان باش ، و ئهو قزتابييّن مهر دوو، ئانكوّ دهيك و بابيّن وان خواندهوارن، و و

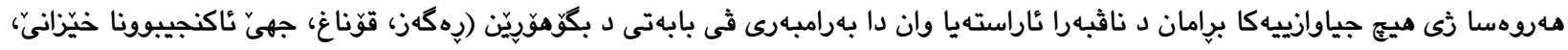

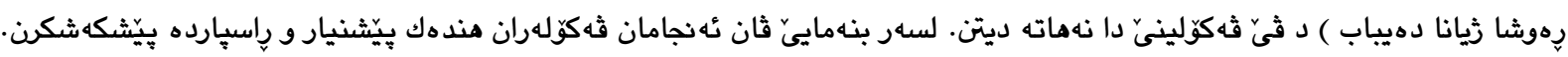

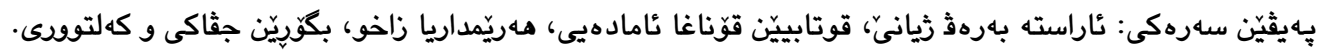

\section{MEANING OF LIFE'S ORIENTATION OF HIGH SCHOOLS STUDENTS IN THE CITY OF ZAKHO}

\begin{abstract}
:
The search aims to identify Meaning of life's orientation of high schools students in the city of Zakho in general and its relationship with some social and cultural variables, and also to identify statistical differences between their view of point depending on the variables (gender, class, family economic state, family's economic state, parents educational level, residence in town or villages, parents living). The sample of research consisted of (271) students selected in whole from the Zakho's high schools according to random sampling method. For this purpose researchers used scale meaning of life's which has been prepared by D. A. Leontev, consisting of (20) items, where extracted psychometric properties, and for the purpose of processing data was used appropriated statistical methods, frequency distribution, mean deviation, standard deviation, T-test, ANOVA. The results shows a positive level of life orientation among most of the students, also found there is statically significant differences according to variables of (family's economic level and level of parents academic state) and also found there is no statically significant differences according to variables of (sex, class, students' family residence and state of parents' life), and in the light of the results researchers presented some recommendations and suggestions.
\end{abstract}

Keywords: life's orientation, high school's students, City of Zakho, social and cultural variables. 